\title{
Implementation Of A Principal System Based On Prisoners' Independence Principles In Indonesia
}

\author{
Saiful Sahri', MJ Saptenno², J.D Pasallbessy ${ }^{2}$, AL Laturette ${ }^{2}$ \\ ${ }^{1}$ Graduate Student PhD, Study Program : Science Of Law. Pattimura University, Ambon, Indonesia \\ ${ }^{2}$ Faculty of Law. Pattimura University, Ambon, Indonesia \\ DOI: 10.29322/IJSRP.11.12.2021.p12015 \\ http://dx.doi.org/10.29322/IJSRP.11.12.2021.p12015
}

\begin{abstract}
The problem of the correctional system for prisoners after returning to society is something that must be addressed in the form of state policy in this case the government. A complicated problem that must receive the government's attention is the issue of the Prisoners' Independence Principle. The problems in this study are related to (1) the nature of the regulation of the principle of independence in prisons in Indonesia. (2) Implementation of guidance based on the principle of independence of prisoners in Indonesia. (3) The implementation model of self-reliance for prisoners in Indonesia. This research was carried out using a normative type of research. Materials to be analyzed are primary and secondary legal materials using a statutory approach (statute approach), and conceptual approach ( conceptual approach) and historical approach (historical approach.
\end{abstract}

Keywords : regulation, principle, independence

\section{INTRODUCTION}

Indonesian criminal law adheres to Law Number 1 of 1946 concerning the Criminal Code (hereinafter referred to as the Criminal Code) and Law Number 8 of 1981 Supplement to the State Gazette of the Republic of Indonesia Number 3209 concerning the Indonesian Criminal Procedure Code (hereinafter referred to as the Indonesian Criminal Code) . referred to as the Criminal Procedure Code) as well as other criminal legislation that specifically regulates it. Meanwhile, in prohibited criminal acts accompanied by criminal sanctions as referred to in Article 10 of the Criminal Code, there are two types of crimes, namely the main crime and the additional crime, where one of the main crimes is imprisonment in which people who are serving prison sentences are commonly referred to as convicts.

The Republic of Indonesia, which is based on Pancasila, as a revival of the principle of kinship, the shift in orientation in sentencing can be seen by the change in the term from "prison" to "correctional". This has a very basic meaning, which has the intention that the development of prisoners is oriented to actions that are more humane and adapted to the conditions of the prisoners.

The term "correctional" was first introduced in Indonesia by Sahardjo in his speech entitled "The Banyan Tree for the Protection of the Pantjasila-Manipol/Usdek Law". (Suhardjo, 1963), when the University of Indonesia awarded him the title of Doctor Honoris Causa in the field of Law on July 5, 1963, the essence of which was the purpose of imprisonment in addition to causing suffering to the convict because his freedom of movement was deprived, guiding the convict to repent, educating so that he be a good member of society (Suhardjo 1963).Thinking about the function of punishment is not only imprisonment but also a rehabilitation and social reintegration effort for prisoners inmates. This effort is carried out in an integrated manner between the coaches, those who are fostered, and also the community in order to improve the quality of the inmates of the correctional facility. Suhardjo, (1963) The ultimate goal of this effort is for the inmates to realize their mistakes, be able to improve themselves, and also not to repeat criminal acts in the future.

Regarding the process of undergoing this criminal or sentencing, it is specifically regulated in Law Number 12 of 1995 concerning Correctional Supplement to the State Gazette of the Republic of Indonesia Number 3614 (hereinafter referred to as UUPAS) accompanied by implementing regulations such as Government Number 99 of 2012 concerning the second Amendment to Government Regulation Number 32 of 1999 concerning the Terms and Procedures for the Implementation of the Rights of Correctional Inmates. (hereinafter referred to as WBP).

Before the penitentiary system, in Indonesia there was a system of imprisonment and treatment for imprisoned people at that time based on the Gestichten Reglement Staatsblad 1917 No. 708 . The prison system itself places great emphasis on the elements of retaliation and deterrence, and is gradually inconsistent with the concepts of social rehabilitation and reintegration.

Discussing the direction of thought about criminal law and its application, cannot be separated from the influence of "stromingen in het straf rechtlijke denken" which is known in criminal law itself so far. Omen, (1977) This means that we are invited to enter a very long time tunnel until the second part of the 18th century, since the emergence of the classical school, and then return to the emergence of the "defence sociale nouvelle" school, which presents a new conception of criminal law (Omen, 1977). 
The science of law since its establishment has always influenced criminal law. The well-known schools, in turn, have also influenced and colored both legal science and criminal law itself. The phases of the development of criminal law that have been known so far show several important characteristics. The most important feature of the first phase developed by the classical school is the formulation of criminal acts in the law. The crime committed takes the central point, so that the color of the criminal law developed in this phase is what is called daadstrafrecht. The most important feature of the second phase developed by the modern or positive stream is the discovery of the causes of criminal acts, where the perpetrators of the crimes developed in the second phase are characterized by what is called daderstrafrecht. Over time, the neo-classical flow emerged which was a combination of classical and positive flow. A prominent feature of this phase is not only the formulation of criminal acts in the law but also retaliation for the mistakes of the maker.

From this description, it cannot be denied that the direction of thinking about criminal and criminal law from time to time continues to develop. Sahetapy in emphasizing the reality of the development of this direction of thought, emphasized that:

Time keeps turning from daadsstrafrecht to daderstraftrecht. It would not be an exaggeration if I saw that the issue of criminal law enforcement has entered the stage of dienstenstrafreht time. If what is thought and stated above is true, then criminal law has become a very powerful target for social action.

Van Bemmelen argues that if we approach criminal law from the point of view of law enforcement, we are no longer inclined to discard criminal law. In this case, we will realize that these orders and prohibitions must always exist because certain unlawful acts, which are impossible for the community to accept will still occur, and the government will not allow the prosecution of violations to be in the hands of individuals. One reason why criminal law needs to exist is that criminal law carefully points out the matters in which the state has the right to act against a citizen through criminal procedure law (Van Bemmelen,1973).

Nigel Walker outlines that criminal law should not be used for retaliation, to punish behavior that does not cause harm to achieve goals that can be achieved by other means at a lower cost, if the losses caused by punishment are greater than those caused by the crime itself. Do not prohibit things that do not have public support, and do not regulate things that are impossible to implement.

Regarding the problem of criminal functions in general, McConnel also gave 5 (five) categories, namely; 1. Expiration; 2. Retribution; 3. Deterrence; 4. Reformation; 5. Social utility.124a. Molly Cheang concluded that criminal sanctuaries contain multiple functions, namely:

1. Rehabilitation of the convicted offender into a noncriminal member of society; 2. Isolation of the offender from society to prevent criminal conduct during the period of confinement; 3. Deterrence of other members of society who might have criminal tendencies similar to those of the offender (secondary deterrence) an deterrence of the offender himself after release (primary deterrence);4. Community condemnation or the reaffirmation of societal norms for the purpose of main training respect for the norms themselves; 5. Retribution or the satisfaction of the community's social and emotional desire to punish the offender (community condemnation is distungulable from retribution in theat the former is reprobative and the latter vindicative)(Sahetapi, 1986).

In addition, Herbert L. Packer who adheres to the view of an integrative criminal function concludes 2 (two) categories, namely; 1 . Crime prevention; 2 . Apply suffering to the perpetrators of criminal acts. Adherents of teleological theory view crime as something that can be used to achieve benefits, both related to the guilty person, for example making him a better person, or related to the world, for example by isolating and improving criminals or preventing potential criminals, will make the world becomes a better place. Bentham, a utilitarian, states that no matter how much punishment brings suffering, its reliability, which strengthens its application, can more than negate crime.

The retributivists state that the punishment that should be accepted is indispensable for reasons of both justice and some moral values. Inappropriate punishment always creates injustice and harms moral values. Kant, one of the characters, stated that the application of a criminal that is not appropriate for any purpose is the use of humans as a tool rather than considering it as an end in itself.

According to the retributists, punishment contains moral values that are free from other consequences that are expected to be further. "Citeris paribus", the world will be better, when moral values are protected by giving suffering to criminals. This causes sometimes this retributive view is categorized as the theory of "the vindicative theory of punishment" (the theory of revenge). In this connection Stanley Grupp remembers that the notion of retribution must be seen in a cultural context that is time and place dependent. Retributive teleological theory teaches the understanding of a pluralistic criminal purpose, because it connects teleological principles (eg utilitarianism), and retributive principles (eg justice) in a single unit, so this view is often referred to as inclusive theory or integrative theory.

According to the view of this school, criminal and sentencing is a program consisting of a process of activities against perpetrators of criminal acts which in a certain way are expected to be able to assimilate (re-assimilate) prisoners into society. The community actually asks that the convict be treated in such a light but effective way, even if it cannot be said to be absolutely satisfactory.

On the basis of defending and defending human rights in a state of law, Sahardjo, SH (Minister of Justice), on July 5, 1953, put forward an idea that correctional is the goal of imprisonment in Indonesia. This was stated in his speech entitled "The Banyan Tree of Protection" at the awarding of Doctor Honoris Causa in the field of science at the University of Indonesia. In his speech, Sahardjo determined that the banyan tree for protection was a legal symbol to be used as a symbol for the Ministry of Justice to serve as an extension agent for its officers in treating prisoners. Under the banyan tree of protection that we have set as extension officers for officers in treating prisoners, the purpose of imprisonment is formulated as: 
"Besides causing suffering to the convicts because of the loss of freedom of movement, guiding the convicts to repentance, educating them so that they become useful members of Indonesian society." With the attitude of the purpose of the crime is correctional (Dindin Sudirman, 2015).

Along with this, Sahardjo formulated his ideas more concretely related to the treatment of prisoners based on Indonesian personalities, so on April 27, 1964 to May 7, 1964, prominent prison officials at their service conference in Lembang Bandung agreed on a conception of "treatment of prisoners" oriented to Pancasila. This new system, known as the Correctional System, focuses its views on the stance that humans, including those who are convicted, as creatures of God are in the unity of the relationship of life, life and livelihood that exists between humans and their personalities, humans and each other, humans and society, humans as as a whole, humans with their nature and humans as God's creatures, humans with their Creator (Dindin Sudirman, 2015).

In the conference, it was reaffirmed the formulation that penitentiary is a process of mutual cooperation, a process that moves multi-functionally and simultaneously, namely, first, to prisoners and others concerned as well as to other elements, prisons move towards their personal development through association with integrity of life, life and livelihood. Second, simultaneously, correctional facilities also move towards the social development of the integrity of life, life and livelihood. Both lead to one goal, namely a just and prosperous society based on Pancasila. (Dindin Sudirman, 2015).

Currently, correctional facilities in Indonesia have undergone significant changes, especially regarding the method of treatment of prisoners themselves. Sahardjo has put forward the idea of penalization for the convicts. On the grounds that "everyone is a social being; no one lives outside the community; then the convicts are only sentenced to lose their freedom of movement " (M. Zen Abdullah,2009).

Related to this, Bahrudin Soerjobroto argues that "correctional is stated as an effort to achieve the unity of life, life, and livelihood that exists between individual lawbreakers and their personalities as humans, between violators and fellow human beings, between offenders and society and nature, all of which are under protection. Almighty God "(Bahrudin Soerjobroto,1986).

Based on Article 14 paragraph (1) of Law Number 12 of 1995 concerning Corrections and Government Regulation Number 99 of 2012 concerning the second Amendment to Government Regulation Number 32 of 1999 concerning Terms and Procedures for the Implementation of the Rights of Correctional Inmates, the rights possessed by prisoners are formulated such as the right to worship, the right to physical and spiritual care, health services, education and teaching and other rights that should be protected and guaranteed. In other words, people who are serving a criminal period, their citizenship and human rights will not be lost.

The Correctional System functions to prepare inmates to interact in a healthy manner with the community, so that they can play their role again as free and responsible members of society. Furthermore, Soejono Dirdjosisworo argues "What is meant by prisoner coaching is all efforts to improve the disabled citizens or prisoners with the direct and minimal intention of avoiding repetition of the behavior that causes the judge's decision. Prisons have correctional duties and function in providing guidance to prisoners or students, providing guidance, preparing facilities and managing work results, maintaining security and order, as well as carrying out prison household administrative affairs. The correctional system is identical with social reintegration, the convict is not only an object but also a subject in coaching (Soejono D.Sosio,1985).

After the inmates carry out their obligations, the correctional officer is obliged to provide the rights they have as a form of efforts to fulfill the rights of prisoners in the context of fulfilling guarantees for the enforcement of Human Rights in Correctional Institutions. Law Number 12 of 1995 concerning Corrections Article 14 paragraph (1) states that prisoners have the right to worship according to their religion or belief, receive treatment both spiritually and physically, receive education and teaching, receive health services and proper food, convey Complaints, get reading materials and follow other mass media broadcasts that are not prohibited, get wages or premiums for the work done, receive family visits, legal counsel, or certain other people, get a reduction in the criminal period (remission), get the opportunity to assimilate including visiting leave family, get parole, get leave before being released, and get other rights in accordance with the applicable laws and regulations.

The normative formulation as mentioned above shows that prisoners have rights that must be upheld, including the right to obtain education and teaching (Harsono,1995).

One of the rights of prisoners according to Article 14 paragraph (1) letter $\mathrm{c}$ of the UUPAS is the right to receive education and teaching. This is an implementation of the constitutional provisions as regulated in the 1945 Constitution of the Republic of Indonesia Article 31 paragraph (1) which states "every citizen has the right to education".

Education is an important thing in human life, including citizens and residents of the Republic of Indonesia, this means that every human being has the right to receive and hope to always develop in education. Basically, education provides us with the knowledge of how to behave, speak and study the development of science, which in the end can be used for many audiences. Education in general has the meaning of a life process in developing each individual to be able to live and carry on life, so being an educated person is very important.

The Correctional Institution (hereinafter referred to as LAPAS) is one of the technical implementing units within the Ministry of Law and Human Rights which has the main task of carrying out the correction of prisoners/students. One of the functions of prisons is to carry out a coaching function which is a process of the correctional system as a realization of criminal reform, which was formerly known as prison, as well as a process of fostering inmates who view prisoners as creatures of God, individuals and members of society.

The implementation of prisoner development based on the correctional system aims to make prisoners become fully human, as has become the direction of national development, through an approach to strengthening their faith and fostering them to be able to integrate properly in group life while in correctional institutions and wider life (society) after carry out his sentence.(Directorate of Community Guidance, Guidelines for parole, 2005). 
UPAS in its general explanation contains a statement that the purpose of punishment is an effort to awaken prisoners and criminal children to regret their actions, and return them to be good citizens, obey the law, uphold moral, social and religious values, so as to achieve a safe community life, orderly and peaceful. (Sudaryono \& Natangsa Surbakti, 2005).

As a coaching institution as well as a law enforcement institution, prisons are part of the Integrated Criminal Justice System. In addition to its role as law enforcement, correctional institutions have a strategic role in the formation of independent, responsible, qualified and dignified Human Resources (HR) (Bambang Supriyono,2012). In line with the role of the prisons, it is appropriate if the correctional officer entrusted with coaching and WBP safeguards in law - this law established as Functional Officer Law Enforcement.

During the correctional process, prisoners are given personality and independence development, the point of which is to return prisoners to a good, confident, independent, active and productive society. Thus, these coaching activities must pay attention to various aspects of the prisoners' livelihood in order to have strong independence and self-confidence (Sismolo, et.al ,2010). Along with the increasingly complex community life that prisoners will face when they return to society, increasing the role of prisons as a vehicle for fostering becomes the most appropriate and unavoidable choice.

LAPAS as an organization has duties and functions that are as important as other institutions in the Criminal Justice System, such as the Police, Prosecutors and Courts. The duties and functions of prisons are to carry out guidance for prisoners and correctional students. In carrying out its duties and functions, LAPAS implements a system in accordance with the General Provisions (Article 1) of the UUPAS. Based on the provisions of the UUPAS, correctional facilities are used as a method of coaching for prisoners and students. Meanwhile, prisoners are humans who face difficulties and their social status is disturbed so that they need guidance.

Guidance for prisoners in general includes, treatment, general education, religious education, as well as skills education or work that has to do with the community. In order to achieve optimal results from the implementation of the correctional system, it will be very dependent on the method.

It is hoped that when they finish serving their criminal period, the ability to overcome all the problems they face will be useful in improving their social interaction with the community. This is in line with the speech of the Minister of Justice of the Republic of Indonesia Sahardjo on July 5, 1963 that era concerning Indonesian law which functions as a protector, it was stated that the purpose of implementing prison sentences was correctional. With the birth of the Correctional System, there has been a new era in the treatment of prisoners, and is currently being strengthened by the birth of the UUPAS.

In the purpose of this sentencing, prisoners are treated as subjects of guidance through resocialization and rehabilitation efforts. Especially considering that prisons are one of the supporting sub-systems that play an important role in the success of the Criminal Justice System. This is understandable, because it is in LAPAS that new human outputs are expected to be truly useful for themselves, their families and the outside community.

Furthermore, Sahardjo stated that in addition to causing pain to the convicts because of the loss of freedom of movement, prisons also have the responsibility to guide prisoners to repent, educate them so that they become useful members of Indonesian society (Sahardjo,1964). It is not only the people who are protected against the repetition of evil deeds by the convict, but also people who have gone astray are protected by providing them with provisions for life as useful citizens in society. So that later prisoners can be useful in society after completing their sentences, prisoners must be given work and education. The work and education provided to prisoners may not be time-consuming or only for the benefit of the prison service or the interests of the state at any time.

Work must be one with work in society and be aimed at national development (Sahardjo,1964). This means that the penitentiary system contains a noble desire to educate prisoners who have been considered lost to become human beings who are useful to the nation and state. In realizing this noble desire, prisoners are not only educated and given skills, but also guided to be socialized. With the correctional system, prisoners are not only objects but also subjects in the coaching process. In this regard, the correctional system has a coaching strategy, especially regarding the coaching process and program. The coaching process is defined as a coaching stage that starts from the intramural coaching stage (in prisons) and moves gradually in accordance with the progress of the coaching results towards coaching that is carried out in the midst of the community (extramural). This stage of the development process is intended to minimize the destructive impact of "imprisonment" in the form of stigmatization, prisonization and recidivism.

In practice, this stage of the coaching process requires community participation, support and control which significantly determines the success of the process itself. Guidance for prisoners in general includes treatment, general education, religious education as well as skills education/work related to the community. To achieve optimal results from the implementation of the correctional system, it is very dependent on the methods and development programs. At the time of the conception of the penitentiary system that was born 50 years ago, this was considered a fundamental change to the philosophy of punishment, because the philosophy of punishment turned into a philosophy of development which was marked by recognizing the dignity of prisoners as human beings, restoring the dignity of prisoners and preparing to return to society. An important issue to be questioned about this philosophy is what kind of coaching method is appropriate for today's prisoners and with the conditions in society.

Problems arise in the form of questions, namely "how can the coaching be carried out". The problem in the form of this question should be the main topic to find concepts and/or theories in the field of prisoner development in the Indonesian Correctional System, because there is no way there is one coaching method that is able to aspire to success for all kinds of prisoners and the differences in conditions of prisons with world conditions. External factors must also be considered. For this reason, the conception of the correctional system must be developed into various coaching methods that are adapted to the characteristics of prisoners and the conditions of a correctional institution. 
According to the labeling theory developed by Schrag, Petrus Panjaitan (1995), Evil acts or crimes themselves are interpreted as the result of a state of social disorganization and crime is caused by various things of a social nature such as industrialization, rapid social change and modernization (Muhammad Mustofa ,2007), Crime is not the quality of actions committed by people, but as a result of the application of rules and sanctions by other people to an offender, or what is known as the Labeling theory, which has changed the context of criminology studies, namely from criminals to the process of crime, which is a new school in criminology.

In the criminal law system there are several sanctions that can be given if someone violates the law. Based on Article 10 of the Criminal Code, criminal sanctions consist of basic and additional penalties. The main punishment consists of capital punishment, imprisonment, confinement, fines, and imprisonment, while the additional punishment itself consists of revocation of certain rights, confiscation of certain goods, and announcement of judge's decision. Imprisonment is imposed if a person who because of his actions violates the law and is found guilty and is sentenced to imprisonment in a trial and the decision has permanent legal force. Imprisonment is a crime for loss of freedom of movement and a form of crime in the form of restriction of movement carried out by closing the perpetrator of a criminal act in a correctional institution, by requiring that person to obey all the rules and regulations that apply in the correctional institution. In practice in the field, there are many obstacles and obstacles, including many forms of violence and discrimination in prisons. This situation causes the purpose of imprisonment in our country to be less effective.

The correctional system is one of the options for reforming the implementation of prison sentences which contains new efforts to implement prison sentences and new ways of treating prisoners based on humanitarian principles. The Indonesian Correctional System is a criminal process that shows activities with a systems approach and efforts to re-socialize prisoners who are recognized as individual beings as well as social beings. The focal point of correctional activities is focused on the personal guidance and guidance of everyone who is a prisoner in order to become a good citizen of the community. The process of imprisonment in prisons as a catalyst for achieving these goals is an integration process that integrates all aspects of society in an integral way, including aspects of the life of prisoners. The correctional process is a mutual cooperation process that exists between prisoners, officers and the community. Therefore, in the perspective of human rights and to provide "justice" treatment of prisoners who are subject to imprisonment, it is not absolutely necessary to use violent means.

Furthermore, as a refinement of the UUPAS as "ius constitutum", it takes "ius constituendum" to become "ius constitutum" related to correctional facilities and this has been formulated in the Bill on Corrections which is included in the 2020 Prolegnas to be enacted into law, and there are some of the new material content added to this bill as conveyed by the Deputy Chair of Commission III of the DPR RI Erma Suryani Ranik as Chair of the Panja, including:

1. Strengthening the position of correctional institutions in the integrated criminal justice system that carries out law enforcement in the field of treatment of prisoners, children, and foster families.

2. Expanding the scope of the goal of the correctional system which not only improves the quality of prisoners and prisoners, but also guarantees the protection of the rights of prisoners and children.

3. The renewal of principles in the implementation of the correctional system is based on the principles of protection, nondiscrimination, humanity, mutual cooperation, independence, proportionality, loss of independence as the only suffering, and professionalism.

4. Regulation on the function of correctional which includes services, guidance, community guidance, care, security, and observation.

5. Enforcement of rights and obligations for detainees, children, and inmates.

6. Arrangements regarding the implementation and provision of community guidance service programs, as well as the implementation of maintenance, security, and observation.

7. Regulation on the support of intelligence activities in the implementation of security and observation functions.

8. Regulation of the code of ethics and code of conduct for correctional officers as well as guarantees for the protection of the rights of correctional officers to carry out security protection and legal assistance in carrying out their duties and functions.

9. Regulation regarding the obligation to provide facilities and infrastructure in the implementation of the correctional system, including the correctional information technology system.

10. Regulation on supervisory function of correctional.

11. Cooperation and community participation carried out in the context of implementing the correctional system.

This change at the same time provides a renewal of the principles in the implementation of the correctional system, one of which is the principle of independence. The principle of self-reliance is the ability, commitment, and effort to provide for the needs of spiritual and physical life for oneself. In correctional, this principle is needed to develop self-potential based on or pay attention to the abilities of the residents and clients of the correctional facility. The principle of independence encourages the fulfillment of the right of guidance which is directed to guidance based on the values of Pancasila, in the form of inculcating a family spirit, skills, spiritual education, and the opportunity to practice worship to encourage the ability of residents and clients of correctional institutions to undergo the process of social reintegration while serving a criminal period, so that they can become independent and productive person (Academic Draft of the Correctional Bill,2020).

That if you pay attention to the problems in prisons within the Unitary State of the Republic of Indonesia, then the problem of the correctional system for prisoners after returning to society is something that must be addressed in the form of state policy, in this case the government.

A complicated problem that must receive the government's attention is the issue of the Prisoners' Independence Principle. Therefore, in order to follow up on the issues and problems that occur, the author feels the need to conduct an in- 
depth and comprehensive research on the problem with the dissertation title "Principles of Prisoners' Independence in Indonesia".

1. To find out, analyze and discover the nature of the correctional system regulation based on humanitarian principles in prisons in Indonesia?

\section{RESEARCH METHOD}

Research is a systematic, directed and purposeful scientific activity. Therefore, the material or information collected must be relevant to the problem at hand. This means that the data is related, relevant and accurate (Kartini Kartono in Marzuki). A method is a way of working or working procedures to be able to understand the object that is the target of the science concerned. The method is a guide for how a scientist learns and understands the steps he faces (Soerjono Soekanto and Sri Mamudji,2007).

\section{RESULTS AND DISCUSSION}

\section{The nature of the regulation of the principle of independence in prisons in Indonesia}

\section{Institutional Structure of Social Institutions}

Correctional institutions as mentioned in the Decree of the Minister of Justice of the Republic of Indonesia Number M.01-PR.07.03 of 1985 concerning the Organization and Work Procedure of Correctional Institutions are technical implementing units in the field of Corrections which are under and directly responsible to the Head of the Regional Office of the Ministry of Justice.

Prisons have the task of carrying out the correction of prisoners/ students (Article 2 Decree of the Minister of Justice of the Republic of Indonesia Number M.01-PR.07.03 of 1985 concerning the Organization and Work Procedures of Correctional Institutions), Furthermore, to carry out this task, prisons have the following functions: (Article 3 Decree of the Minister of Justice of the Republic of Indonesia Number M.01-PR.07.03 of 1985 concerning the Organization and Work Procedures of Correctional Institutions)

a. Conducting training for prisoners/students;

b. Provide guidance, prepare facilities and manage work results;

c. Conduct social/spiritual guidance for prisoners/students;

d. Carry out maintenance of security and order in prisons;

e. Perform administrative and household affairs.

Prisons are classified into 4 classes based on capacity, place of residence, and place of work activities. The four classes are : (Article 4 Regulation of the Minister of Law and Human Rights of the Republic of Indonesia Number M.HH-05.OT.01.01 of 2011 concerning Amendments to the Decree of the Minister of Justice of the Republic of Indonesia Number M.01-PR.07.03 of 1985 concerning Organization and Work Procedures of Institutions Correctional)
a. Class I prisons;
b. Class IIA prisons;
c. Class IIB Prison; and
d. Class III Prison.

Class I (one) prisons consist of: (Article 25 of the Decree of the Minister of Justice of the Republic of Indonesia Number M.01-PR.07.03 of 1985 concerning the Organization and Work Procedures of Correctional Institutions)
a. Administrative Section;
b. Convict Development Sector;
c. Field of Work Activities;
d. Security Administration and Order;
e. Prison Security Unit.

The Administrative Section has the task of carrying out the administrative and household affairs of the prison. (Article 6 Decree of the Minister of Justice of the Republic of Indonesia Number M.01-PR.07.03 of 1985 concerning the Organization and Work Procedures of Correctional Institutions). Furthermore, Article 7 states that in order to carry out the tasks mentioned in Article, the Administrative Section has a function;

a. carry out employment matters;

b. conduct financial affairs;

c. do correspondence, equipment and household affairs.

The Administration Section consists of: (Article 8-Article 9 of the Decree of the Minister of Justice of the Republic of Indonesia Number M.01-PR.07.03 of 1985 concerning the Organization and Work Procedures of Correctional Institutions)

a. Sub-Division of Personnel which has the task of carrying out personnel affairs

b. Sub Division of Finance which has the task of carrying out financial affairs

c. The General Sub-Section has the task of carrying out correspondence, equipment and household affairs

The Convict Guidance Sector has the task of carrying out prisoner correctional development. (Article 10 Decree of the Minister of Justice of the Republic of Indonesia Number M.01-PR.07.03 of 1985 concerning the Organization and Work Procedures of Correctional Institutions) To carry out this task, the Convict Development Division has the following functions: 
(Article 11 Decree of the Minister of Justice of the Republic of Indonesia Number M.01-PR.07.03 of 1985 concerning the Organization and Work Procedures of Correctional Institutions)

a. Registering and making statistics and documentation of prisoners' fingerprints;

b. Provide correctional guidance;

c. Take care of health and provide care for prisoners.

The Convict Development Division consists of: (Article 12-Article 13 Decree of the Minister of Justice of the Republic of Indonesia Number M.01-PR.07.03 of 1985 concerning the Organization and Work Procedures of Correctional Institutions)

a. Registration Section, has the task of recording and making statistics and documentation of prisoners' fingerprints

b. The Community Guidance Section, has the task of providing spiritual guidance and counseling as well as providing sports training, increasing knowledge of assimilation, leave and release of prisoners;

c. The Prison Care Section has the task of taking care of health and providing care for prisoners.

The Field of Work Activities has the task of providing work guidance, preparing work facilities and managing work results. (Article 14 Decree of the Minister of Justice of the Republic of Indonesia Number M.01-PR.07.03 of 1985 concerning the Organization and Work Procedures of Correctional Institutions) To carry out this task, the Work Activities Division has the following functions: (Article 15 Decree of the Minister of Justice of the Republic of Indonesia Number M.01-PR.07.03 of 1985 concerning the Organization and Work Procedures of Correctional Institutions)

a. Provide job training guidance for prisoners;

b. Prepare work facilities;

c. Manage work results.

Fields of Work Activities consist of: (Article 16-Article 17 of the Decree of the Minister of Justice of the Republic of Indonesia Number M.01-PR.07.03 of 1985 concerning the Organization and Work Procedures of Correctional Institutions)

a. The Work Guidance Section has the task of providing instructions and guidance on job training for prisoners;

b. Work Facilities Section, has the task of preparing work facilities

c. Work Results Management Section, has the task of managing work results

Article 18 states that the Security Administration and Order Division has the task of regulating the task schedule, the use of equipment and the division of security tasks, receiving daily reports and minutes from the security unit in charge as well as compiling periodic reports in the security sector and enforcing rules and regulations. Furthermore, in Article 19, to carry out this task

The Security and Order Administration Division has the following functions:

a. Manage task schedules, use of equipment and division of security tasks;

b. Receive daily reports and minutes from the security unit in charge and prepare periodic reports in the security sector and enforce rules and regulations.

The Security and Order Administration Division consists of: (Article 20-Article 21 of the Decree of the Minister of Justice of the Republic of Indonesia Number M.01-PR.07.03 of 1985 concerning the Organization and Work Procedures of Correctional Institutions)

a. Security Section, has the task of managing the schedule of tasks, the use of equipment and the division of security tasks.

b. The Reporting and Discipline Section has the task of receiving daily reports and minutes from the security unit on duty and preparing periodic reports in the security sector and enforcing rules and regulations.

The prison security unit as mentioned in Article 22 has the task of maintaining prison security and order. To carry out this task, the prison security unit has the following functions : (Article 23 Decree of the Minister of Justice of the Republic of Indonesia Number M.01-PR.07.03 of 1985 concerning the Organization and Work Procedures of Correctional Institutions).

a. Carry out guarding and supervision of prisoners;

b. Carry out maintenance of security and order;

c. Supervise the reception, placement and release of prisoners;

d. Conduct inspections for security breaches;

e. Make daily reports and minutes of security implementation.

The organizational structure of Class IIA prisons is regulated starting from Article 25 to Article 44 of the Decree of the Minister of Justice of the Republic of Indonesia Number M.01-PR.07.03 of 1985 concerning the Organization and Work Procedure of Correctional Institutions. The arrangement consists of:

a. Sub Division of Administration;

b. Section for Guidance of Prisoners/Protects;

c. Work Activities Section;

d. Section of Administration of Security and Order;

e. Prison Security Unit

The Administrative Sub-Section has the task of carrying out administrative and household affairs in prisons. To carry out this task, the Administration Sub-Section has the following functions:

a. Carry out personnel and financial affairs;

b. Doing correspondence, equipment and household affairs. 
The Administration Sub-Section consists of:

a. Personnel and Financial Affairs, has the task of carrying out personnel and financial affairs

b. General Affairs, has the task of doing correspondence, equipment and household affairs

The Guidance Section for Prisoners / Students has the task of providing correctional guidance for prisoners / students. To carry out this task, the Guidance Section for Prisoners / Students has the following functions:

a. Registering and making statistics and documenting fingerprints of prisoners/students;

b. Provide correctional guidance, take care of health and provide care for prisoners/students.

The Guidance Section for Prisoners/Students consists of:

a. Registration Sub-Section, has the task of recording and making statistics and documenting fingerprints of prisoners/students

b. The Sub-Section of Community Guidance and Care, has the task of providing spiritual guidance and counseling as well as providing sports training, increasing assimilation knowledge, releasing leave and welfare of prisoners/students as well as taking care of health and providing care for prisoners/students.

The Work Activities Section has the task of providing work guidance, preparing work facilities and managing work results. To carry out this task, the Work Activities Section has the following functions:

a. Provide job training guidance for prisoners/students and manage work results;

b. Prepare work facilities.

The Work Activities Section consists of:

a. The Sub-Section of Guidance and Management of Work Results, has the task of providing instructions and guidance on job training for prisoners/students as well as managing work results.

b. The Work Facilities Sub-Section has the task of preparing work facilities facilitation.

The Security Administration and Order Section has the task of managing the task schedule, use of equipment and division of security tasks, receiving daily reports and minutes from the security unit on duty as well as compiling periodic reports in the security sector and enforcing rules and regulations. To carry out this task, the Security and Order Administration section has the following functions:

a. Manage task schedules, use of equipment and division of security tasks;

b. Receive daily reports and minutes from the security unit in charge and prepare periodic reports in the security sector and enforce rules and regulations.

The Security and Order Administration Section consists of:

a. Security Sub-Section, has the task of managing task schedules, use of equipment and division of security tasks.

b. The Reporting and Order Sub-Section has the task of receiving daily reports and minutes from the security unit in charge and preparing periodic reports in the security sector and enforcing rules and regulations.

The Prison Security Unit has the task of maintaining prison security and order. To carry out this task, the prison security unit has the following functions:

a. Carry out guarding and supervision of prisoners/students;

b. Carry out maintenance of security and order;

c. Supervise the reception, placement and release of prisoners/students;

d. Conduct inspections for security breaches;

e. Make daily reports and minutes of security implementation.

The prison security unit is led by a head and supervises the prison security officer who is under and directly responsible to the head of the prison.

The organizational structure of Class II B prisons is regulated in Articles 45 to 60 of the Decree of the Minister of Justice of the Republic of Indonesia Number M.01-PR.07.03 of 1985 concerning the Organization and Work Procedures of Correctional Institutions consisting of: (Article 45 of the Decree of the Minister of Justice of the Republic of Indonesia Number M.01-PR.07.03 of 1985 concerning the Organization and Work Procedures of Correctional Institutions)

a. Sub Division of Administration;

b. Section for Guidance of Prisoners/Students and Work Activities;

c. Section of Administration of Security and Order;

d. Prison Security Unit.

The Administrative Sub-Section has the task of carrying out the administrative and household affairs of the prison. To carry out these tasks, the Administration Sub Division has the following functions:

a. Carry out personnel and financial affairs;

b. Doing correspondence, equipment and household affairs.

Administration Sub Division consists of:

a. Personnel and Financial Affairs have the task of carrying out personnel and financial affairs.

b. General Affairs has the task of carrying out correspondence, equipment and household affairs.

The Guidance Section for Prisoners / Students and Work Activities has the task of providing correctional guidance for prisoners / students and work guidance. To carry out these tasks, the Section for Guidance of Prisoners / Students and Work Activities has the following functions:

a. Registering and making statistical documentation of fingerprints and providing correctional guidance for prisoners/students;

b. Taking care of health and providing care for prisoners/students; 
c. Provide work guidance, prepare work facilities and manage work results

The Guidance Section for Prisoners / Students and Work Activities consists of:

a. The Sub-Section for Registration and Community Guidance has the task of recording, making statistics, documenting fingerprints and providing spiritual guidance and counseling, providing sports training, increasing assimilation knowledge, leaving and releasing prisoners/students.

b. The Sub-Section for Care of Prisoners/Protects, has the task of taking care of health and providing care for prisoners/students.

c. The Work Activities Sub-Section has the task of providing work guidance, preparing work facilities and managing work results.

The Security Administration and Order Section has the task of managing the task schedule, use of equipment and division of security tasks, receiving daily reports and minutes from the security unit on duty as well as compiling periodic reports in the security sector and enforcing rules and regulations. To carry out this task, the Security and Order Administration has the following functions:

a. Manage task schedules, use of equipment and division of security tasks;

b. Receive daily reports and minutes from the security unit in charge and prepare periodic reports in the security sector and enforce rules and regulations.

The Security and Order Administration Section consists of:

a. The Security Sub-Section has the task of managing the task schedule, the use of equipment and the division of security tasks.

b. The Reporting and Order Sub-Section has the task of receiving daily reports and minutes from the security unit on duty and preparing periodic reports in the security sector and enforcing rules and regulations.

The Prison Security Unit has the task of maintaining prison security and order. To carry out this task, the Prison Security Unit has the following duties:

a. carry out guarding and supervision of prisoners/students;

b. carry out maintenance of security and order;

c. supervise the receipt, placement and release of prisoners/students;

d. conduct inspections for security breaches;

e. make daily reports and minutes of security implementation.

The Prison Security Unit is led by a Head and oversees the Prison Security Officer who is under and directly responsible to the Head of the Prison.

Class III prisons consist of: (Article 60 letter a Regulation of the Minister of Law and Human Rights of the Republic of Indonesia Number M.HH-05.OT.01.01 of 2011 concerning Amendments to the Decree of the Minister of Justice of the Republic of Indonesia Number M.01-PR.07.03 of 1985 concerning Organization and Administration Correctional Work.)

a. Administrative Affairs;

b. Admission and Orientation Subsection;

c. Development Subsection; and

d. Security and Order Subsection.

Furthermore, Article 60 letter b to letter e explains that Administrative Affairs has the task of carrying out planning, staffing and finance, administration, equipment and household affairs as well as preparing evaluation materials and preparing reports. The Admissions and Orientation Subsection has the task of conducting registration and database, assessment and classification, information services and receiving complaints. The Development Subsection has the task of carrying out personality development, independence development, community guidance, food and equipment services for prisoners and health services. The Security and Order Subsection has the task of administering security and order, preventing and taking action against disturbances in security and order.

So, if viewed based on the organizational structure of the Penitentiary, it can be seen that prisons are only given authority in terms of carrying out their duties and functions as community institutions without being given more or extra authority in carrying out prosecution, investigations or other preventive and repressive powers.

\section{Prison Independence Principle}

Correctional Institution is a place to carry out the guidance of Prisoners and Correctional Students as regulated in Article 1 point 3 of Law Number 12 of 1995 concerning Corrections. Whereas in Article 1 point 1 of Law Number 12 of 1995 concerning Corrections, what is meant by correctional is an activity to carry out guidance for prisoners in prison based on the system, institution and method of coaching which is the final part of the criminal justice system in the criminal justice system. From this understanding, it can be seen that the core of correctional facilities is the development of prisoners so that later they can return to society properly. This development requires a system, which is called the correctional system.

Law No. 12 of 1995 concerning Corrections regulates the correctional system, which is an order regarding the directions and boundaries as well as the method of fostering correctional inmates based on Pancasila which is carried out properly. The community is fostered properly in order to improve the quality of correctional inmates so that they are aware of their mistakes, improve themselves and do not repeat criminal acts, so that they can be accepted back in the community, and can also play an active role in development and can live normally as good and responsible citizens. responsibility as stated in Article 1 Paragraph (2) which says that: 
Article 1 Paragraph (2): The Correctional System is an order regarding the direction and boundaries as well as the method of fostering Correctional Inmates based on Pancasila which is carried out in an integrated manner between the coaches, those who are fostered, and the community to improve the quality of Correctional Inmates so that they are aware of their mistakes, improve themselves, and do not repeat criminal acts so that they can be accepted again by the community, can play an active role in development, and can live normally as good and responsible citizens.

Penitentiary is a Technical Implementation Unit under the Directorate General of Corrections of the Ministry of Law and Human Rights (formerly the Ministry of Justice). The occupants of the Correctional Institution can be inmates (convicts) or Correctional Inmates (WBP) or those whose status is still in custody, meaning that the person is still in the judicial process and has not been determined guilty or not by the judge.

Civil servants who handle the development of prisoners and detainees in correctional institutions are called Correctional Officers, or previously known as prisons. The concept of penitentiary was first conceived by the Minister of Justice in 1962, where it was stated that the task of the prison service was not only to carry out sentences, but a much more difficult task was to return people who had been convicted of a crime to society.

In Article 4 of Law no. 12 of 1995 concerning Corrections states that prisons and prisons are established in every district or municipal capital, but if deemed necessary, at the sub-district or administrative city level, prison branches and prison branches can be established. Furthermore, the guidance for the inmates is carried out in prisons and the guidance for the inmates is carried out by the prison as regulated in Article 6 of Law Number 12 of 1995 concerning Corrections.

Prison is a place for carrying out the construction of prisoners and correctional students. From this understanding, essentially they have similarities, namely people who inhabit prisons based on court decisions, and the difference can be explained by the Correctional Law, based on Article 1 paragraph (7) and paragraph (8), a convict is a convict or a person convicted based on a court decision that has obtained permanent legal force, who has served a sentence or has lost independence in prison.

The correctional system is a series of criminal law enforcement units, therefore its implementation cannot be separated from the development of a general conception of punishment. The correctional system in addition to aiming to restore the prisoners as good citizens, also aims to protect the community against the possibility of repeating criminal acts by correctional inmates. Dwidja Priyatno, (2006), Penitentiary as the spearhead of the implementation of the principle of protection is a place to achieve the goals of the correctional institution by providing guidance and development through education, rehabilitation, and integration.

Imprisonment with the penitentiary system in Indonesia currently refers to Law Number 12 of 1995 concerning Corrections. The Correctional Law consists of 8 chapters and 54 articles. As for the first chapter regulates general provisions, the second chapter regulates guidance, the third chapter regulates the fostered community members, the fourth chapter regulates the community consideration center and community observer team, the fifth chapter regulates security and order, the sixth chapter regulates other provisions, chapter the seventh regulates the transitional regulations, the eighth chapter regulates the closing provisions.

The general explanation of the Correctional Law which is the philosophical juridical basis regarding the implementation of the correctional system in Indonesia states that:

a. For the Indonesian state, which is based on Pancasila, new ideas regarding the function of punishment which are no longer just a deterrent but also an effort to rehabilitate and reintegrate Prisoners have given birth to a coaching system which for more than thirty years has been known and is called the correctional system.

b. Although various improvements have been made regarding the order (cells) of punishment, such as conditional criminal provisions (Article 14a of the Criminal Code), conditional release (Article 15 of the Criminal Code), and special provisions for the prosecution and punishment of children (Articles 45, 46, and 47 of the Criminal Code), but basically the nature of punishment is still based on the principle and system of imprisonment, the prison system emphasizes the elements of revenge and deterrence, so that the institutions used as a place of development are prison houses for convicts and state education houses for guilty children.

c. The prison system which emphasizes the elements of revenge and deterrence accompanied by the institution of "prison house" is gradually being seen as a system and means that is not in line with the concept of rehabilitation and social reintegration, so that inmates are aware of their mistakes, no longer have the will to commit acts of violence. and return to being responsible citizens for themselves, their families and their environment.

Based on this thought, since 1964, the punishment system for convicts and criminal children has changed fundamentally, namely from a prison system to a correctional system. Similarly, the institution which was originally called a prison house and a state education house turned into a correctional institution based on the Instruction Letter of the Head of the Directorate of Corrections Number JHG8/506 dated June 17 , 1964 (Dwidja Priyatno, 2006).

The development of coaching for prisoners is closely related to the purpose of punishment. Prisoners' guidance which is now being carried out initially started from the fact that the purpose of sentencing was no longer in accordance with the development of values and essences that grew in society (CIHarsono, (1995), The purpose of the treatment of prisoners in Indonesia began in 1964 after Sahardjo stated in a prison conference, so that those who were prisoners were no longer made a deterrent but were fostered and then re-socialized (Soedjono, 1972).

Article 2 of Law Number 12 of 1995 concerning Corrections states that the correctional system is held in order to form Correctional Inmates to become fully human, realize mistakes, improve themselves, and do not repeat criminal 
acts so that they can be accepted again by the community, can play an active role. in development, and can live naturally as good and responsible citizens. Furthermore, the objectives of the Correctional Institution are:

a. Forming Correctional Inmates to become fully human, aware of mistakes, improve themselves and not repeat criminal acts so that they can be accepted again by the community, can actively play a role in development and can live naturally as good and responsible citizens.

b. Provide guarantees for the protection of the rights of prisoners held in the State Detention Center and Branches of the State Detention Center in order to facilitate the process of investigation, prosecution and examination in court

c. Provide guarantees for the protection of the human rights of prisoners / litigants as well as the safety and security of confiscated objects for the purposes of evidence at the level of investigation, prosecution and examination in court as well as objects declared confiscated for the state based on court decisions.

The function of the Correctional Institution as stated in Article 3 of the Correctional Law is to prepare correctional inmates to be able to integrate in a healthy manner with the community, so that they can play a role again as free and responsible members of society. What is meant by healthy integration is the restoration of the unity of the relationship between the inmates and the community. In the correctional system, prisoners and correctional students have the right to receive spiritual and physical guidance and are guaranteed their rights to carry out their worship, to communicate with outside parties, both family and other parties, to obtain information both through print and electronic media, to obtain proper education and so on. (Dwidja Priyatno,2006).

To implement the correctional system, community participation is also needed, both with an attitude of being willing to accept back prisoners who have finished serving their sentences .

Guidance for inmates is part of the correctional system to enforce criminal law. Based on Article 2 and Article 3 of the Correctional Law, it can be seen that the purpose of the correctional system is to return the inmates to become good citizens so that they can be accepted back into the community.

The principle of correctional development is a guide or guide for the coaches of inmates so that the objectives of the guidance carried out can be achieved properly. Based on Article 5 of the Correctional Law, namely: the principle of protection, the principle of equality of treatment and service, the principle of education, the principle of guidance, the principle of respect for human dignity, the principle of losing independence is the only suffering, the principle of guaranteeing the right to keep in touch with family and friends. certain people.

According to Article 5 of the Correctional Law, the elaboration of the principles of the guidance system for prisoners is:

a. shelter

What is meant by "protection" is the treatment of prisoners in prison in the context of protecting the community from repeating criminal acts by inmates by providing debriefing through the coaching process (A Josias Simon R and Thomas Sunaryo, 2010).

b. Equality of Treatment and Service

All Prisoners in Correctional Institutions are treated and served the same without discriminating against people's backgrounds (non-discrimination)

c. Education and Mentoring

Services in this field are based on the spirit of kinship, character, spiritual education, opportunities to worship, and skills based on Pancasila.

d. Respect for Human Dignity and Dignity

This principle is explained as a form of treatment for inmates who are considered "lost" people, but must be treated as human beings.

e. Losing freedom is the only suffering

What is meant above is that the inmates are only temporarily placed in the Correctional Institution to receive rehabilitation from the state

f. Guaranteed right to keep in touch with family and certain people

There are efforts to be brought closer and introduced to the community so that it does not cause alienation by visiting, entertaining in prisons, and gathering with friends and family.

The principles of coaching, in principle, include 3 correctional thoughts, namely as goals, processes and methods, namely : (Romli Atmasasmita, 1996)

a. As a meaningful goal, with correctional guidance, it is hoped that prisoners can realize their actions and return to being obedient and obedient citizens of the applicable law

b. As a process means various activities that must be carried out during the coaching and mentoring takes place

c. As a method, it is a way that must be taken to achieve the goal of coaching and mentoring with the correctional system.

The whole process of fostering prisoners with the correctional system is an integral unit to return prisoners to society with the provision of abilities (mental, physical, expertise, integration, as far as possible financial and material) needed to become good and useful citizens.

\section{Social System}

Seeing the correctional system as a treatment system for prisoners in Indonesia since 1964 with resocialization as the goal, it cannot be separated from how the prisoner development process is carried out.

The correctional process in terms of security is divided into 4 (four) stages : (Bachliar Agus Salim. 1985) 
a. First stage: Maximum security stage, up to betas S! of the actual criminal period.

b. The second stage: The medium security stage, up to of the actual criminal period.

c. Third stage: Minimum security stage, up to T limit! of the actual criminal period.

d. Fourth stage: Integration stage, from the completion of T! actual criminal period until the end of the sentence.

The first stage: the maximum security stage ; prisoners at this stage are subject to strict supervision, if necessary armed guard, especially for dangerous convicts. This stage is up to S! of the actual criminal period. This stage begins with the admission and orientation stage, namely since entering, being registered, examining the letters of the verdict, the length of the sentence, calculating when he was released and others, and conducting research to find out all things about him. The results of this study are very important for the preparation of further coaching programs, what education/jobs are suitable, and where they should be fostered. The admission and orientation phase lasts a maximum of one month.

The second stage: the medium security stage; At this stage, the supervision of prisoners is looser when compared to the first stage. Have been able to work or exercise outside the correctional institution with escort by the correctional officer. This stage is up to of the actual criminal period.

The third stage: the minimum security stage ; this stage starts from to T! actual criminal period. At this stage, it can be assimilated out of the correctional institution without supervision. This assimilation, for example, worshiping, exercising, attending education, working outside the correctional institution together with the general public without escort, is only in the nature of supervision and guidance from correctional officers. In the third stage. Prisoners can be assimilated to the outside, namely working outside the correctional institution; in the morning leaving and in the afternoon returning to the correctional institution in the context of being independent (self-employed) in a fixed place; for example as a barber, or in a private company, for example as an employee in a factory or in a government agency, for example as a driver.

Fourth stage: integration stage; at this stage, when you have done T! criminal period and at least 9 months a prisoner can be proposed to be granted parole. At this integration stage, the convict is fully in the midst of the community or his family, only later when his parole period has expired (criminals served while undergoing parole) he returns to the nearest correctional institution to take care of / complete his release / release letter. By getting a release letter from this penitentiary, his status as a prisoner is gone. If in this fourth stage it is difficult or impossible to be granted parole (because the conditions may be difficult to obtain, for example a statement from the victim previously containing no objection that he was granted parole) then he may be granted leave before release (CMB) of the same length with the duration (number) of the last remission, but not more than 6 months.

The stages described above are only given if the prisoner really follows the rules that are in the correctional institution and follows the guidance given by the correctional officers diligently so that he behaves well and never gets disciplinary punishment. But if he behaves badly then he will not be able to move up to the next stage or for example he has behaved well and moved up to the next stage, for example he is already in the fourth stage, but he makes a riot, organizes a rebellion in the prison, or run away and then caught again, then he returns to the first stage (maximum security stage ).

For this reason, ideally every correctional institution is only intended for convicts/students at the maximum security stage only or for the medium security stage only or for the minimum security stage only, which is called a " Single Purpose " correctional institution ( Bachliar Agus Salim. 1985)

In Indonesia, one penitentiary carries out all three stages, meaning that one correctional institution for the maximum security, medium security and minimum security stages together, only separated by its own block, for example block A for maximum security, block B for medium security and block C for the minimum security stage, this kind of correctional institution is called a " Mufti Purpose " correctional institution. (Bachliar Agus Salim. 1985)

Currently, the Government (Directorate General of Corrections at the Ministry of Justice) has planned/towards a correctional institution that will only be intended for convicts in the maximum security stage and the medium security stage; and correctional institutions which are only for the minimum level of security. This is the so-called " duaIpurpose " penitentiary, (Bachliar Agus Salim. 1985)

According to the Correctional System, prisoners/students are not allowed to leave the dual-purpose correctional institution (convicts/students in the maximum security and medium security stages ) without escort. It can be justified leaving the correctional institution without escort at the minimum security stage, namely in the context of assimilation/integration, with the community.

The current penitentiary is multi-purpose, so that the public cannot know whether the inmates outside the prison without escort have met the requirements for assimilation/integration or not.

To determine whether a prisoner behaves well or not, this is determined by the results of a session of a council called the Correctional Board of Trustees (DPP).

Romli Atmasasmita, responding to the four-phase coaching method stated that there are several things that should be stated; (Romli Aimasasmita. 1971).

First, it seems that the originators and inventors of the coaching method patterned on the correctional process mentioned above tend to divide the lives of prisoners while serving their sentences based on the time variable. Starting from inmates entering the Intensive Prison, it is carried out.

Second, as a consequence of the first thing above, it can be said that, it will be very difficult for correctional officers to provide a mental assessment and behavior of a prisoner as long as the good and bad judgment of a convict is still limited by the time limit factor as described above. earlier. Doesn't one's mental or behavior know no time limit? This can be evidenced by an example of how difficult it is to regulate the life of an inmate who has just 
entered a correctional institution compared to those who are classified as recidivist (those who have repeatedly committed crimes) as experienced by correctional officers. In fact, after they are released in the outside community, they commit crimes again. It seems that the good and bad judgment of a prisoner must have been considered so that the outside community (in a limited sense) also gives their impressions since a prisoner undergoes assimilation.

Third, apart from these four correctional processes, there are still weaknesses in terms of the coaching methodology and in its implementation instructions; also still requires the support of legislation that is directed and comprehensive. It is clear from the provisions regarding the correctional process and also from the author's observations in several correctional institutions. that in terms of supervision and security rather than the implementation mechanism of the four stages of the correctional process, there are still weaknesses. Several cases that occur where there are prisoners who escape or "leave" in the context of assimilation or ordinary leave or pre-release leave are examples of the weaknesses referred to above.

Fourth, in the implementation of the four stages of the correctional process, there are still clashes or lack of understanding or misunderstanding on the part of officers from other agencies such as the Police or the Prosecutor's Office regarding the implementation of prisons. It appears here that information and correctional extension officers in order to strengthen the implementation of correctional facilities in relation to the law enforcement process as a whole have not been intensively implemented.

After the issuance of Law no. 12/1995, the development of prisoners is regulated in Government Regulation Number 31 of 1999 in Article 7 paragraph (2), that the development of prisoners consists of 3 (three) stages, namely:

a. Early stage

b. Advanced stage, and

c. Final stage.

Furthermore, in Article 9 paragraphs (1, 2 and 3) of PP No. 31/1999 explained about the stages of the development. The initial stage of coaching starts from the time the person concerned is a prisoner up to $S$ ! from the penitentiary. The advanced stage of development includes: 1 . The first advanced stage, starting from the end of the initial stage of development up to of the criminal mesa. The second Advanced stage, since the end of the first Advanced stage development until T! criminal period. The final stage of guidance is carried out from the end of the Advanced stage until the end of the criminal prison of the prisoner in question. For prisoners who are sentenced to life imprisonment, the stages as mentioned above are not carried out.

According to Article 10 PP No. 31/1999 that:

1. The initial stage of development as referred to in Article 9 paragraph (1) includes: a. the period of observation, introduction and environmental research is a maximum of 1 (one) month; b. planning of personality and self-reliance development programs; c. implementation of personality and independence development programs; and D. assessment of the implementation of the early stage coaching program

2. Advanced stage coaching includes:

a. Advanced development program planning;

b. implementation of the follow-up coaching program;

c. evaluation of the implementation of the Advanced development program and;

d. planning and implementing assimilation programs.

3. The final stage of coaching, including:

a. Integration program planning;

b. Implementation of integration programs and;

c. The end of the implementation of the final stage of construction

4. The stages of development as referred to in paragraph (1), paragraph (2) and paragraph (3) are determined through a session of the Correctional Observer Team.

5. In the session of the Correctional Observer Team, the head of the correctional institution must pay attention to the results of the cross.

In connection with that in Article 11 PP No. 31/1999 stated that:

1. The initial and advanced stages of development are carried out in correctional institutions.

2. The final stage of coaching is carried out outside the prison by BAPAS.

3. In the event that the convict does not meet certain conditions, the final stage of development of the convict concerned will still be carried out at the LAPAS.

In the General Elucidation of Law no. 12/1995 which is the juridical basis of philosophy regarding the implementation of the correctional system in Indonesia, it is stated that:

1. For the Indonesian state, which is based on Pancasila, new ideas regarding the function of punishment are no longer just a deterrent but also an effort to rehabilitate and reintegrate the prisoners in the correctional system, which has given birth to a system of coaching that has been known for more than thirty years and is known as the correctional system.

2. Although various improvements have been made regarding the order (stelsel) of punishment, such as conditional criminal institutions (Article 14a of the Criminal Code), conditional release (Article 15 of the Criminal Code), and special institutions for determining and punishing children (Articles 45, 46, and 47 of the Criminal Code). Basically, the nature of punishment is still based on the principle and system of imprisonment. The prison system emphasizes 
the elements of revenge and deterrence, so that the institutions used as a place of development are prison houses for convicts and state education houses for guilty children.

3. The prison system which emphasizes the elements of revenge and deterrence accompanied by the institution of a "prison house" is gradually being seen as a system and means that is not in line with the concept of rehabilitation and social reintegration, so that prisoners realize their mistakes, no longer have the will to commit crimes. and return to being responsible citizens for themselves, their families, and their environment.

From the general explanation above, it is clear that the function of punishment is to carry out rehabilitation and social reintegration so that prisoners realize their mistakes and improve themselves so that they can return to being good and useful citizens.

Penitentiary as the spearhead of the implementation of the principle of protection is a place to achieve the goal of coaching through education, rehabilitation, and reintegration.

In line with the role of the correctional institution, the correctional officers who carry out the task of coaching, securing, and guiding the Correctional inmates in Law no. 12/1995 was appointed as a Law Enforcement Functional Officer.

The correctional system aims to restore Correctional Inmates as good citizens and also aims to protect the community against the possibility of repeating criminal acts by Correctional Persons, and is an application and an inseparable part of the values contained in Pancasila. The Indonesian correctional system emphasizes the aspects of fostering prisoners, correctional students, or correctional clients who have preventive, curative, rehabilitative, and educative characteristics.

Although the penitentiary system has been in place since 1964, various legal instruments that formally underlie it still originate from the Dutch East Indies period, which are the system and characteristics of prisons. Although in its implementation it has been based on new ideas and values contained in Pancasila, the characteristics of imprisonment are still inherent in some correctional officers.

Correctional institutions as a forum for fostering prisoners, in essence, must be able to play a role in full human development as a forum for educating convicted humans to become quality human beings.

The function of the correctional institution is as an educational institution and at the same time as a development institution that is able to increase added value for prisoners, by sharpening the prisoner development program (prison inmates). For example, by increasing the weight of skills, training inmates' independence, increasing the productivity of work results, all of which are nothing but self-defense, both mentally and spiritually, before returning to society. In other words, the correctional facility as a place for fostering prisoners must be able to function as an educational and development institution,(Adi Sujaino. 1993).

The dual role of correctional institutions, both as educational institutions and development institutions, is stated in the discretion of the Ministry of Justice of the Republic of Indonesia which is stated in the Decree of the Minister of Justice of the Republic of Indonesia No. M. 02-PK.04.10 of 1990 concerning the pattern of fostering prisoners/detainees, which among other things emphasizes the following: "With this premise, the concept of correctionalism, in essence, is also Pancasila correctional which plays a role in development so that it is also one of the an educational institution and a development institution".

To achieve the goal of fostering prisoners, it is necessary to develop an open and productive prison with the aim of participating in promoting socio-economic activities, for their own interests and for the sake of development.

The functions of open and productive prisons, which are abbreviated as open prisons, are:

1. Educational institutions that educate human prisoners in the context of creating human qualities.

2. Development institutions that include human prisoners to become productive people of development.

With these characteristics, correctional institutions not only have to change in the pattern of coaching that is carried out, but at the same time they have to change their orientation from consumptive institutions to productive institutions." As stated earlier, it was Sahardjo who had the idea of reforming or improving the law in force at that time and it was stated in his inaugural speech when he received the title of Doctor Honoris Causa from the University of Indonesia in 1963, with the title: "The Banyan Tree for Protection ", which directly concerns the fate of inmates in prison.

According to Adi Suyatno, the basic ideas and ideas include the following:

1. The banyan tree for protection as a symbol of law in Indonesia

2. The task of the law is to provide protection so that the noble ideals of the nation are achieved and maintained.

3. Under the banyan tree, not only the community is protected against the repetition of evil deeds by the convict, but also people who have strayed are protected by providing them with life provisions as useful citizens in society.

In Article 5 of Law no. 12/1995 it is stated that the Correctional Development System is implemented based on the following principles:

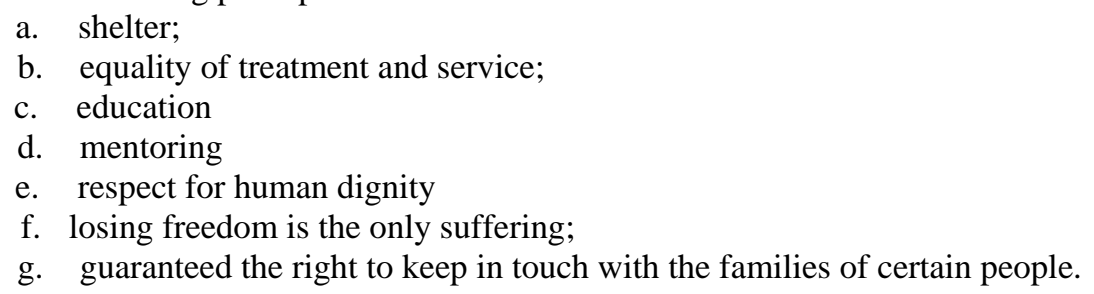


According to Patta Parang (1997) the definition of "principle of protection" is that by conducting community development it will be protected from the possibility of committing a crime again by the inmates, as well as providing life provisions in the form of skills so that they can become useful citizens in society. So with this principle both the community and the citizens terayomi building.

The definition of "the principle of equality of treatment and service" is to provide equal treatment and services to all inmates without discriminating against people. This means that in terms of coaching there is no difference between the poor and the rich, there is no difference between the poor and the rich. ordinary people with former officials. They will get the same rights, for example in terms of parole if the conditions for that have been met.

"The principle of education and guidance" is that education and guidance is based on Pancasila. Therefore, education and guidance is carried out to instill awareness of society, nation and state, religious awareness and skills education.

The meaning of "the principle of respect for human dignity and dignity" is that even though the inmates are lost, they should not be insulted, yelled at or given work that is not fair and so on.

While the definition of "the principle of losing independence is the only suffering" is that inmates must be in a correctional institution for a certain period of time, so that the state has full opportunity to improve it as long as they are in a correctional institution and still have their rights as human beings, in other words their civil rights remain. protected, such as obtaining health care, food, drink, clothing, bedding, skills training, sports and so on.

Then the understanding with the principle of "guaranteeing the right to keep in touch with certain families and people" is that even though they are in a correctional institution, they must still be brought closer and introduced to the community and should not be isolated from them, for example, relate to the community in the form of visits. , entertainment into the penitentiary of free members of society, the opportunity to gather with family, as well as with other people such as religious leaders, lawyers and others.

Regarding the guidelines for the implementation of coaching carried out in correctional institutions, it is regulated in Article 10 of Law no. 12/1995 as follows:

1. Convicts admitted to correctional institutions must be registered.

2. The registration as referred to in paragraph (I) changes the status of the convicted person to a prisoner.

3. The head of the correctional institution is responsible for the admission of convicts and the release of prisoners in the correctional institution.

Placement of convicts in correctional institutions is carried out in accordance with Article 270 of the Criminal Procedure Code and registration is carried out when the convict is received at the correctional institution. Likewise, his release is carried out when the prisoner has finished serving his criminal period, what is meant by release in this case includes the release or release of the prisoner from the correctional institution.

According to Article 2 of Law no. 12/1995 the purpose of holding a correctional system in order to form Correctional Inmates so that they become fully human, are aware of mistakes, improve themselves, and do not repeat criminal acts, so that they can be accepted back by the community, can play an active role in development and can live normally as citizens who good and responsible.

In the explanation of Article 2 of Law no. 12/1995 what is meant by "to become fully human", is an effort to restore Prisoners and Correctional Students to their nature in the relationship between humans and their God, humans with their personalities, humans with each other, and humans with their environment.

In Article 3 of Law no. 12/1995 states that the function of the correctional system is to prepare Correctional Inmates to be able to integrate in a healthy manner with the community, so that they can play a role again as free and responsible members of society. What is meant by "healthy integration" is the restoration of the unity of the relationship between the Prisoners and the community.

Based on the provisions of Article 6 of Law no. 12/1995, it is stated that the Guidance of Correctional Inmates is carried out in a correctional institution and the guidance of Correctional Inmates is carried out by BAPAS. Meanwhile, guidance in correctional institutions is carried out for prisoners and students in prison.

The Guidance of Correctional Inmates in LAPAS is carried out:

a. intramurally ( $\mathrm{dl}$ in prison) and

b. extramurally (outside prison)

Intramural guidance carried out in correctional institutions is called assimilation, which is the process of fostering Correctional Inmates who have met certain requirements by integrating them into community life.

Extra mural coaching is also carried out by BAPAS which is called integration, which is the process of mentoring Prisoners who have met certain requirements to live and be back in the midst of society with the guidance and supervision of BAPAS.

Article 6 paragraph (3) of Law no. 12/1995 it is stated that the guidance by BAPAS is carried out on:

a. Conditional convicts;

b. Prisoners, criminal children and state children who get parole or leave before being released;

c. State children based on court decisions, the guidance is handed over to the social agency's foster parents;

d. State Children who based on the decision of the Minister or Officials in the Directorate General of Corrections who are appointed, the guidance is handed over to foster parents or social agencies; and

e. Children who are based on court decisions, their guidance is returned to their guardian parents.

Guidance by BAPAS for State Children which, based on court decisions, is handed over to foster parents or social agencies, because the mentoring is still the responsibility of the Government. For State Children whose guidance 
is submitted to foster parents or social agencies, the guidance is still carried out by BAPAS because the child is still a State Child. The supervision by BAPAS towards children based on the determination of the court, the assistance is returned to the parents or the wall is carried out as long as there is a request from the parents or the wall to BAPAS.

Correctional which is the final part of the criminal justice system in the judicial system is an integral part of the integrated criminal justice system. With advertising, correctional facilities, both in terms of systems, institutions, training methods, and correctional officers, are an integral part of a series of law enforcement processes.

\section{CONCLUSION}

The regulation of the independence of prisons in Indonesia has in principle been regulated in Law Number 12 of 1995 concerning Corrections and other implementing regulations related to prisons, but its implementation in these regulations, prisons are not given absolute authority (attribution) in the context of managing the prison. itself based on the principles of independence of the correctional system.

\section{REFERENCES}

1. A Josias Simon R and Thomas Sunaryo, 2010, Cultural Studies of Correctional Institutions in Indonesia, Lubuk Agung, Bandung, p.1.

2. Academic Draft of the Correctional Bill. Retrieved 07 May 2020

3. Adi Sujaino. 1993. Efforts Towards Implementation of an Open Penitentiary in Class 1 Sukamiskin Penitentiary Bandung. Paper. delivered at the National Seminar on Convict Correctional II. Jakarta: Faculty of Law. Ul Hal. 13.

4. Article 10 Decree of the Minister of Justice of the Republic of Indonesia Number M.01-PR.07.03 of 1985 concerning the Organization and Work Procedures of Correctional Institutions

5. Article 11 Decree of the Minister of Justice of the Republic of Indonesia Number M.01-PR.07.03 of 1985 concerning the Organization and Work Procedures of Correctional Institutions

6. Article 12-Article 13 Decree of the Minister of Justice of the Republic of Indonesia Number M.01-PR.07.03 of 1985 concerning the Organization and Work Procedures of Correctional Institutions

7. Article 14 Decree of the Minister of Justice of the Republic of Indonesia Number M.01-PR.07.03 of 1985 concerning the Organization and Work Procedures of Correctional Institutions

8. Article 15 Decree of the Minister of Justice of the Republic of Indonesia Number M.01-PR.07.03 of 1985 concerning the Organization and Work Procedures of Correctional Institutions

9. Article 16-Article 17 of the Decree of the Minister of Justice of the Republic of Indonesia Number M.01-PR.07.03 of 1985 concerning the Organization and Work Procedures of Correctional Institutions

10. Article 2 Decree of the Minister of Justice of the Republic of Indonesia Number M.01-PR.07.03 of 1985 concerning the Organization and Work Procedures of Correctional Institutions

11. Article 20-Article 21 of the Decree of the Minister of Justice of the Republic of Indonesia Number M.01-PR.07.03 of 1985 concerning the Organization and Work Procedures of Correctional Institutions

12. Article 23 Decree of the Minister of Justice of the Republic of Indonesia Number M.01-PR.07.03 of 1985 concerning the Organization and Work Procedures of Correctional Institutions.

13. Article 25 of the Decree of the Minister of Justice of the Republic of Indonesia Number M.01-PR.07.03 of 1985 concerning the Organization and Work Procedures of Correctional Institutions.

14. Article 3 Decree of the Minister of Justice of the Republic of Indonesia Number M.01-PR.07.03 of 1985 concerning the Organization and Work Procedures of Correctional Institutions

15. Article 4 Regulation of the Minister of Law and Human Rights of the Republic of Indonesia Number M.HH05.OT.01.01 of 2011 concerning Amendments to the Decree of the Minister of Justice of the Republic of Indonesia Number M.01-PR.07.03 of 1985 concerning Organization and Work Procedures of Institutions Correctional

16. Article 45 of the Decree of the Minister of Justice of the Republic of Indonesia Number M.01-PR.07.03 of 1985 concerning the Organization and Work Procedures of Correctional Institutions.

17. Article 6 Decree of the Minister of Justice of the Republic of Indonesia Number M.01-PR.07.03 of 1985 concerning the Organization and Work Procedures of Correctional Institutions

18. Article 60 letter a Regulation of the Minister of Law and Human Rights of the Republic of Indonesia Number M.HH05.OT.01.01 of 2011 concerning Amendments to the Decree of the Minister of Justice of the Republic of Indonesia Number M.01-PR.07.03 of 1985 concerning Organization and Administration Correctional Work.

19. Article 8-Article 9 of the Decree of the Minister of Justice of the Republic of Indonesia Number M.01-PR.07.03 of 1985 concerning the Organization and Work Procedures of Correctional Institutions

20. Bachliar Agus Salim. 1985. Criminal Prison in the Criminal System in Indonesia. Dissertation, Medan : University of North Sumatra, Pg. 188-189

21. Bahrudin Soerjobroto, Correctional Sciences (Short View), Jakarta: AKIP, 1986. hlm. 8 
22. Bambang Supriyono, Performance Improvement of Class IIB Nusakambangan Open Penitentiary (Paper unpublished), Semarang: Ministry of Law and Human Rights Central Java, 2012. p.1.

23. Chair of the Working Committee for the Correctional Bill Erma Ranik, During a Working Meeting at Commission III DPR, Parliament Complex, Senayan, Jakarta, Tuesday (17/9/2019). Retrieved 07 May 2020.

24. CIHarsono, 1995, A New System of Convict Guidance, Djambatan, Jakarta, p. 13.

25. Dindin Sudirman, 2015. Reflecting on 50 Years of the Correctional System Anatomy of Problems and Efforts to Overcome Them, Jakarta. Center of Detention Studies. p. 59

26. Directorate of Community Guidance, Guidelines for parole, Jakarta: Ministry of Law and Human Rights of the Republic of Indonesia, 2005.hlm.1.

27. Dwidja Priyatno, 2006, Imprisonment System for Imprisonment in Indonesia, Refika Aditama, Bandung, p. 103.

28. Harsono. New System for Convict Development . Jakarta: Bridge. 1995. p. 28

29. Kartini Kartono in Marzuki, Research Methodology, 1st edition, UII Press, Yogyakarta, p.55.

30. M. Zen Abdullah, Prison Crimes of Existence and Its Effectiveness in Efforts to Resocialize Prisoners, Yogyakarta: Hasta Cipta Mandiri, 2009. p. 4.

31. Muhammad Mustofa, Legal Aid for Prison Convicts (Eleged Citizens ) Alumni, Bandung, 2007. p.89.

32. Omen. Voorlopige Hechtenis en Vrijheidsbenemende Straffe. Een Poenametrisch Onderzoek Bij Enkele Vermogensdelicten. Kluwer. Deventer, 1977. p. 22-31-2

33. Patta Parang. 1997. Active Role of Correctional Officers in Guiding Prisoners. tesls. Jakarta: Postgraduate Program. Legal Science. Ul pp.61-64.

34. Petrus Panjaitan, Correctional Institution in the Perspective of the Criminal Justice System, Sinar Harapan Pustaka, Jakarta. 1995. pp. 89-91

35. Romli Aimasasmita. 1971. From Prisoners' Guidance Management. Bandung: Alumni Publisher. page 60

36. Romli Atmasasmita, 1996, Some Notes on the Contents of the Correctional Bill, Rineka, Bandung, p.12.

37. Sahardjo, Banyan Tree for Protection, Home for the Sukamiskin, Bandung, 1964. p.21.

38. Sahetapy. Towards A Victim Policy The Role of The Community. Victim, No.01. Year I. Association for Victim Services. Faculty of Law. Airlangga University. 1986-3

39. Sismolo, et.al, Performance Improvement in the Field of Work Activities in the Context of Realizing Inmates to Become Independent in Class 1 Correctional Institutions Cirebon, Jakarta: Ministry of Law and Human Rights, 2010. p. 2 .

40. Soedjono, 1972, Stories of Prisons in Various Countries, Alumni, Bandung, p. 86.

41. Soejono D.Sosio, Criminology of Social Sciences in Crime Studies, Bandung: Sinar Baru. 1985. p.235.

42. Soerjono Soekanto and Sri Mamudji, Normative Legal Research A Brief Overview, Raja Grafindo Persada, Jakarta, 2007. p.6.

43. Sudaryono \& Natangsa Surbakti, Criminal Law, Surakarta: Faculty of Law, University of Muhammadiyah Surakarta, 2005. p. 320.

44. Suhardjo in a speech at the awarding ceremony for the title of Doctor Honoris Causa in Legal Studies which was delivered on 5 July 1963.

45. Van Bemmelen. Ounces Strafrecht. Deel 1. Tjeenk Willink. Groningen. 1973 -4

\section{AUTHORS}

First author : Saiful Sahri, Graduate Student PhD, Study Program : Science Of Law.

Pattimura University, Ambon, Indonesia : Email : saifulsahri51@gmail.com

The second author : MJ Saptenno : Faculty Of Law. Pattimura University, Ambon, Indonesia

The third author : JD Pasallbessy : Faculty Of Law. Pattimura University, Ambon, Indonesia

The fourth author : AL Laturette, : Faculty Of Law. Pattimura University, Ambon, Indonesia 